\title{
E-tailers versus retailers: which factors determine consumer preferences
}

Citation for published version (APA):

Keen, C. N., Wetzels, M. G. M., de Ruyter, J. C., \& Feinberg, R. A. (2001). E-tailers versus retailers: which factors determine consumer preferences. METEOR, Maastricht University School of Business and Economics. METEOR Research Memorandum No. 040 https://doi.org/10.26481/umamet.2001040

Document status and date:

Published: 01/01/2001

DOI:

10.26481/umamet.2001040

Document Version:

Publisher's PDF, also known as Version of record

\section{Please check the document version of this publication:}

- A submitted manuscript is the version of the article upon submission and before peer-review. There can be important differences between the submitted version and the official published version of record.

People interested in the research are advised to contact the author for the final version of the publication, or visit the DOI to the publisher's website.

- The final author version and the galley proof are versions of the publication after peer review.

- The final published version features the final layout of the paper including the volume, issue and page numbers.

Link to publication

\footnotetext{
General rights rights.

- You may freely distribute the URL identifying the publication in the public portal. please follow below link for the End User Agreement:

www.umlib.nl/taverne-license

Take down policy

If you believe that this document breaches copyright please contact us at:

repository@maastrichtuniversity.nl

providing details and we will investigate your claim.
}

Copyright and moral rights for the publications made accessible in the public portal are retained by the authors and/or other copyright owners and it is a condition of accessing publications that users recognise and abide by the legal requirements associated with these

- Users may download and print one copy of any publication from the public portal for the purpose of private study or research.

- You may not further distribute the material or use it for any profit-making activity or commercial gain

If the publication is distributed under the terms of Article $25 \mathrm{fa}$ of the Dutch Copyright Act, indicated by the "Taverne" license above, 


\title{
E-tailers versus Retailers: Which Factors Determine Consumer Preferences
}

\author{
Cherie Keen \\ Martin Wetzels \\ Ko de Ruyter \\ Richard Feinberg
}

MAXX WORKING PAPER SERIES

Maastricht Academic Center

for research in Services

Maxx 


\begin{abstract}
The growth of Internet technology and electronic commerce has not been matched by theoretically-guided social science research. Clear and well designed consumer research is needed to describe, explain, and predict what will happen to this changing landscape. The primary purpose of this study is to investigate the structure for consumer preferences to make product purchases through three available retail formats - store, catalog, and the Internet. Conjoint analysis was used to assess the structure of the decision and the importance of the attributes in the decision-making process. The results from this study noticeably show that the structure of the consumer decision-making process was found to be primarily one of choosing the retail format (store, catalog, or Internet) and price of product (set at low, medium or high) desired. The strength of the retail store format suggests that fears that the Internet will take over the retail arena seem, at least at this point in time, overblown and exaggerated. However, there seems to be an identifiable segment of customers that has a preference for the Internet as a retail shopping alternative.
\end{abstract}




\section{E-TAILERS VERSUS RETAILERS: WHICH FACTORS \\ DETERMINE CONSUMER PREFERENCES}

\section{INTRODUCTION}

Although there has been much research to identify important attributes in the consumer decision-making process for shopping at retail stores and through catalogs, research has not yet focused on the drivers for consumer choices to use the Internet for product purchase. To identify the impact of e-commerce, consumer behavior research is needed to illustrate a more accurate representation of how consumers will make choices relative to available retail alternatives. In the marketing literature, the focus has not been on the decision process as one of possible tradeoffs. Therefore, we need to examine the consumer behavior literature as well as the more recent work on the acceptance of technology and apply them to this relatively new consumer decision-making process.

By identifying key drivers of retail format selection from both theoretical backgrounds, the goal is to find out which of the attributes are crucial in determining consumer preference regarding retail shopping alternatives. Moreover, theoretical-driven research allows us to expand the power of consumer behavior theories, allowing even greater clarification of the practical issues. In light of these issues, this research has two main objectives: (1) to identify the structure for consumer intentions to make product purchases through three retail alternatives, and (2) to examine the trade-offs consumers are willing to make when deciding through which retail alternative to make a purchase.

Although most retailers, catalogers, and market research companies assume that ecommerce will jolt all other retail formats, academic research has yet to identify if this is the case. As technology increases the alternatives for consumers, it is important to understand what motivates consumers to shop using a particular retail format. The potential growth of 
Internet shopping makes this area fertile for theoretical-driven research. Researchers have examined a number of variables and constructs in an attempt to understand retail format selection and non-store purchasing behavior, but little cohesive organization is yet evident. This research aims to identify how consumers chose the setting they wish for a given consumption purpose. Investigating under what circumstances and what conditions different consumers will accept electronic commerce should provide a new dimension to the current literature. In addition to purchase format, we identify five key elements in the consumer purchase decision-making process: subjective norms, attitude, perceived behavioral control, ease of use and price.

This paper is structured as follows. First we provide a brief synthesis of the existing literature on consumer choice behavior and technology acceptance in a retail context. Secondly, we report on the results of a conjoint experiment designed to empirically assess the consumer decision-making process. We conclude the paper with a discussion of the results and the theoretical and managerial implications.

\section{LITERATURE REVIEW}

One theme that has emerged in the literature on technology use is the link between attitudes and behavioral intentions (Adams, Nelson, \& Todd, 1992; Bagozzi \& Kimmel, 1995; Dabholkar, 1992, 1996; Davis, 1989, 1993; Davis, Bagozzi, \& Warshaw, 1989; Davis \& Venkatesh, 1996; Hill, Smith, \& Mann, 1987; Mathieson, 1991; Taylor \& Todd, 1995). The theory of reasoned action (TRA) (Fishbein \& Ajzen, 1975) has been used successfully to identify key elements of consumer decision-making (Taylor \& Todd, 1995). The TRA proposes that behavior is determined by an individual's intention to perform the behavior, and intention is influenced by attitudes and subjective norms (Ajzen \& Fishbein, 1980). While most of the support for the theory has come from the social psychology literature, there has been success in applying this theory to consumer decision-making (Sheppard, Hartwick, 
\& Warshaw, 1988). Research using TRA has proved to be successful across a number of disciplines and was "designed to explain virtually any human behavior," (Ajzen \& Fishbein, 1980, p.4).

Since it has received support in the attitude and behavior literature, several researchers have refined the theory of reasoned action to enhance its predictive nature on behavior. Two such versions are the theory of planned behavior (Ajzen, 1991, 1988) and the technology acceptance model (Davis, 1993, 1989). Both of these theories have been identified to predict an individual's intention to use some type of technology. The theory of planned behavior (TPB) (Ajzen, 1991, 1988) was designed to predict an individual's behavior across many social and psychological settings and can be applied to Internet shopping. The theory of technology acceptance (TAM) was specifically developed by Davis (1993, 1989) to predict an individual's intention to use an information system and can be modified to predict a consumer's intention to use Internet technology for product purchasing.

Key elements from these two extensions of the theory of reasoned action are used in this research to identify behavioral purchase intentions of consumers for a retail product purchase decision. From research on these two models, four variables were identified as applicable to this research: 1) subjective norms, 2) attitude, 3) perceived behavioral control, and 4) ease of use. Another element that has been identified in both academic and Internet literature, but not extensively tested, is the effect of price on using technology (i.e. would consumers use the Internet only if there was a price savings or would they be willing to pay a premium to use the Internet). Therefore, price was examined in this research as well.

\section{The Theory of Planned Behavior}

The theory of planned behavior can be thought of as an extension of the theory of reasoned action in that it "accounts for behaviors that a decision maker regards as potentially subject to interference by internal or external impediments" (Bagozzi \& Kimmel, 1995, p. 
437). According to the theory, the immediate determinant of behavior is intention to perform the behavior. One of the major limitations of the theory of reasoned action is that it did not deal with behaviors in which individuals have "incomplete volitional control," (Ajzen, 1991, p.181).

The theory of planned behavior (TPB) asserts that behavioral intention is a function of attitude and subjective norm, similar to TRA, but with the addition of perceived behavioral control (PBC). Attitude towards the behavior is determined by the individual's evaluations of the outcomes and an assessment as to how likely the outcome is to occur. Subjective norm refers to the individual's perceptions of the social pressure to perform (or not) the behavior. In respect to the model, Ajzen (1991) defines PBC as the "perception of ease or difficulty of performing the behavior of interest," (p.183). It is believed that behavior is strongly influenced by an individual's confidence in his/her ability to perform a behavior (Ajzen, 1991). Madden, Ellen, and Ajzen (1992) examined the effect of control of ten different behaviors and found that perceived behavioral control predicted intention for all categories. The more an individual believes that the resources and opportunities exit to perform the behavior, the greater their perceived behavioral control over the behavior should be.

Each of the determinants of intention, attitude, subjective norm, and perceived behavioral control are determined by underlying belief structures. It is important to note that these beliefs are the ones that are salient to the individual at the time, not just a broad range of beliefs that could occur (Ajzen, 1991). Attitudes toward the behavior, subjective norm, perceived behavioral control, and intention "each reveals a different aspect of the behavior, and each can serve as a point of attack to change it," (Ajzen, 1991, p.206).

\section{The Technology Acceptance Model}

Davis (1993, 1989) derived a specific theory of reasoned action relating to technology acceptance. The goal of the model is "to provide an explanation of the determinants of 
computer acceptance that is general," (Davis et al., 1989, p.985). By extending the attitude toward behavior - behavioral intention relationship established in the TRA and TPB, Davis (1993, 1989; Davis et al., 1989; Davis \& Venkatesh, 1996) studied adoption of computer software in a workplace setting. The attitude-behavioral intention relationship in the model implies that all else being equal, individuals form intentions to perform behaviors toward which they have a positive effect (Davis, et al., 1989).

The model was designed to understand the causal link of external variables to its user's computer acceptance and use. According to Davis, et al. (1989) the technology acceptance model (TAM) “...is specifically designed to explain computer usage behavior...(p.983). The goal of TAM is to be...capable of explaining user behavior across a broad range of computer technologies and user populations...by identifying a small number of fundamental variables...for modeling the theoretical relationships among these variables," (p.985).

In this model, behavioral intention (BI) to use the technology is determined by the individual's attitude toward using the technology. Attitude (A) toward using is therefore determined by two specific beliefs, perceived usefulness (U) and perceived ease of use (EOU), which were identified from previous research to influence user acceptance (Davis 1993, 1989; Davis, et al.,1989; Hill, et al., 1987). Usefulness is the individual's perception that using the technology will improve his/her performance (Davis, 1993, 1989; Davis et al., 1989; Davis \& Venkatesh, 1996). Assumed to have a direct effect on intention, usefulness is also linked with ease of use to determine attitude. Ease of use is the individual's perception that using the technology will be free of effort (Davis, 1993, 1989; Davis et al., 1989; Davis \& Venkatesh, 1996). Ease of use is thought to have a large amount of influence over first time trials and then influencing the consumer to use the technology again.

The technology acceptance model has received a lot of support in predicting user acceptance. Davis (1986) pioneered the model and continued to validate it (1989, 1993). It 
was then successfully replicated (Davis et al., 1989; Adams et al., 1992; Mathieson, 1991) and research was extended to examine user acceptance (Moore \& Benbasat, 1991; Taylor \& Todd, 1995).

\section{METHODS AND PROCEDURES}

The primary purpose of this study was to explore the structure for consumers' behavioral intentions to use available retail formats (store, catalog or Internet) for product purchases. Using the theory of planned behavior (Ajzen, 1988) and the technology acceptance model (Davis, 1993, 1989) to guide the research, several attributes were identified as likely predictors of consumer intentions to use a particular retail format to make a product purchase.

This research has two main objectives: (1) to identify the structure for consumer intentions to make product purchases through three retail alternatives, and (2) to examine the trade-offs consumers are willing to make when deciding where to purchase. To accomplish the research objectives, conjoint analysis was seen as the appropriate tool to use. According to Green and Srinivasan (1978), conjoint analysis can be used to determine the contributions of predictor variables and their levels when attempting to determine consumer preferences and to establish a valid model of consumer judgements. Once this model is identified, predictions can be made about consumers' acceptance of any combinations of attributes. Several researchers have provided excellent overviews of the conjoint technique (Carroll \& Green 1995; Green \& Srinivasan, 1990; Louviere, 1988).

\section{Design of the Conjoint Analysis Study}

For the conjoint analysis study we choose the part-worth function model, as it provides the most flexibility in terms of functional form of the preference function (Green \& Srinivasan 1978, 1990). Moreover, the full-profile method was employed to collect the data for the conjoint analysis. The full-profile method was utilized because of the realism that the method displays to respondents (Green \& Srinivasan 1978, 1990). A limitation to this approach is the 
possibility of information overload, as it utilizes the complete set of factors. However, the use of fractional factorial designs has been suggested to ameliorate information overload (Addelman 1962; Green \& Srinivasan 1978, 1990).

The respondents were presented with a verbal description for the stimuli using a stimulus card. The dependent variable in the study was intention to purchase. The six independent variables were retail format (three options: Internet, retail, and catalog), price (three options: high, medium, low), control (two options: high, low), ease of use (two options: easy, difficult), subjective norm (two options: high, low), and attitude (two options: positive, negative). Two sample profiles are included in Appendix A. The respondent was requested to respond to the hypothetical profile by giving a rating, on a $0-100$ scale, of how likely they would be to purchase the product given that specific profile. Finally, the OLS procedure was employed to obtain estimates of the parameters, or part-worth utilities.

\section{$\underline{\text { Instrument }}$}

From a measurement perspective, a researcher collecting conjoint data has respondents rate a stimulus consisting of multiple attributes. That is, in conjoint measurement, a respondent considers all factors concurrently for each treatment combination (also called a stimulus, profile, or scenario). Using this analysis, the researcher is able to decompose the evaluations into separate utilities, or part-worths (Green \& Srinivasan 1978, 1990). Data collection is, therefore, more holistic and more ecologically valid because complete situations rather than simple questions are considered. The choice situation for this study is consumer's preferences for a retail format of purchase of consumer products.

This research uses a questionnaire (conjoint rankings) and a scenario. Several researchers in the consumer behavior field have advocated this process instead of the traditional laboratory experiments (Bateson, 1985; Dabholkar, 1992, 1996; Surprenant \& Solomon, 1987). With respect to the terminology that was used for operationalizing the abstract 
conceptualisations encountered in the literature, we felt that we had to 'translate' those into easily understandable and unambiguous (layman's) terms in order to facilitate the data collection procedure. Previous research implicitly and explicitly suggested some of the terms that we could use in our study. For instance, Davis $(1989,1993)$ defines ease of use as the individual's perception that using the technology will be free of effort. Furthermore, we also had to use terminology that could be kept consistent for all three modes of purchase, i.e., retail shopping could hardly be described as 'easy to use'.

\section{$\underline{\text { Product Categories }}$}

Two product categories, a music CD and a personal computer, were tested in this study. Each product was chosen based on frequency of purchase on-line. In most studies examining the shopping trends for Internet purchases, music sales and computer products are consistently listed in the "top three" for category purchase frequency among Web users (Boston Consulting Group, 1998; Ernst \& Young, 1998, 1999; Forrester Research Inc., 1998, 1999; Nielsen Media Research \& CommerceNet 1999). In addition to purchase frequency, other criterion that was used for selecting the products was that each product could reasonably be assumed to be purchased in all three retail alternatives (Internet, catalog, and store-based retailers) and be purchased by a wide range of consumers.

Compared to one another, CDs offer a lower level of risk with the purchase from the consumers' point of view then would a computer. Music CDs are usually low-cost entertainment items purchased for the ability to personally select the music you wish to listen to. Computers have a higher level of risk associated with them since there is larger cost involved in the product. A computer usually has an effect on the ability to perform certain functions, whether for work or for pleasure. Thus, these two product classes offer a good opportunity to develop the theory and implications for academics and practitioners. In addition, researchers who utilize conjoint analysis recommend that some familiarity with the 
product is necessary for a rational evaluation of intent to purchase, which tend to make the evaluations more valid (Nataraajan, 1993).

\section{$\underline{\text { Sample }}$}

The sample consisted of 290 mall shoppers in a Chicago suburb. The use of the mall intercept technique gave the researchers the ability to have face-to-face interviews with the respondents, which was more desirable since the conjoint method was used (Green \& Krieger, 1991; Green \& Srinivasan, 1990). Bush and Hair (1985) found in their comparison study that the overall quality of mall intercept data surpassed that of telephone interviewing and provides for more complete and less distorted responses. Since we wanted to ensure that respondents understood the terms that were used in the scenarios, it was important to provide an opportunity for a more in-depth data collection procedure, which the mall intercept survey provides (Bush \& Hair, 1985).

One of the major concerns when using mall intercept surveys is ensuring the sampling procedure so that the correct respondents are chosen (Bush \& Hair, 1985). Since we preferred a more random sample of the population, quota sampling was not used. Instead, every fifth shopper who passed our data collection point was invited to participate in our study. In order to avoid respondent bias, the research was done over a six-day period that included weekend days and weekdays, as well as different shopping hours. Shoppers were asked if they were familiar with both catalog and Internet modes of shopping before they were asked to complete the survey to assure that they were familiar with each of the retail alternatives that were presented (Nataraajan, 1993). The sample characteristics can be found in Table 1.

$$
[\Leftarrow \text { Insert Table } 1 \text { about here } \Rightarrow]
$$

As can be seen in Table 1, we received consistent results across the two product groups in terms of characteristics. In terms of age, although we did have a variety of ages in the samples, nost of the respondents fell into the $<35$ years age category. This could be one of 
the problems of not using the quota sampling procedure advocated by some mall intercept researchers (Blair, 1983; Sudman, 1980). Since we had a greater proportion of younger $(<35$ years) respondents, it resulted in having a larger proportion of lower income respondents compared to those with incomes of $\$ 55,000$ and higher. The one characteristic in which our two product group samples differed the most was in terms of level of education. For the CD product class, there was a higher percentage of college graduates than in the computer product class, while the computer product class had a higher percentage of graduate school respondents than the CD sample.

The questionnaire was self-administered under the guidance of a surveyor in a private location within the mall. Each respondent was randomly assigned to answer either the $\mathrm{CD}$ or computer survey, but not both, to ensure that there would not be respondent fatigue. In conjoint analysis, respondent fatigue is more likely if respondents must assess large number of profiles in the survey (Green \& Srinivasan, 1978, 1990). Therefore, respondents answered the questionnaire for only one product type. Of the 290 surveys that were collected, 281 were usable. For the CD product survey, 143 responses were usable. For the computer product survey, 138 responses were usable.

\section{ANALYSIS AND RESULTS}

In this paper, we will first estimate the part-worth utilities for individual levels of the attributes for the two product classes, CD's and PC's. On the basis of the part-worth utilities, importance scores can be derived using the range of the part-worth utilities. Furthermore, we will investigate the internal validity of the results using of Pearson's product moment correlation coefficient $(\rho)$ and choice simulations. These importance scores will be used for post hoc segmentation purposes (Green \& Krieger, 1991). Finally, we will use choice simulation to further validate the results of our study. 
Product classes were examined for differences in their importance level to respondents. Since the products are quite different in cost and risk of purchase, it would be assumed that the attributes guiding the purchase would be different. Our results indicate an adequate level of internal validity in terms of Pearson's product moment correlation coefficient $(\rho)$ for both product classes, as they both exceeded $0.99(\mathrm{p}<0.001)$. Aggregate importance scores for each sample are shown graphically in Figure 1 and with data and utility scores in Table 2.

$$
[\Leftarrow \text { Insert Figure } 1 \text { and Table } 2 \text { about here } \Rightarrow \text { ] }
$$

Once the product classes were segregated, differences are apparent in what is most important in the purchase decisions. For the $\mathrm{CD}$ product class, retail format had an importance score of 26.6, while price was second most important. For computers, price had an importance score of 26.1 and retail format was viewed as the second most important attribute. For a lower cost, lower risk item like a $\mathrm{CD}$, retail format may outweigh price because of the convenience factor in the purchase. Most consumers want the CD immediately and may be willing to pay a higher price in order to have the $\mathrm{CD}$ in-hand quickly. Alternatively, with a high cost purchase, consumers would probably shop around for the best price and then make the purchase. For these types of products, it may be worth it to do pricecomparison shopping and then wait for the product.

For the computer product, price was seen as the most important attribute for consumers to make the product purchase. Low cost computers were preferred with a differential of 22.1, meaning that for this product class, it was the driving indicator of whether a purchase would be made or not. For the $\mathrm{CD}$, price was the second most important attribute in the study. The differential between high and low price for this product class was 19.4, indicating that there is quite a high preference for low price alternatives.

Attitude was rated as the third most important attribute for each of the product classes. The importance was greater for the $\mathrm{CD}$ product than for the computer product. Differentials 
between positive, pleasant experiences and negative, unpleasant experiences were 22.9, with the preference for the positive, pleasant experience. For the computer sample, the differential was 18.4, with the preference for the positive, pleasant experience. Control was selected as the fourth most important attribute for each of the product classes, but was higher for the computer product. The differential for the computer product was 13.3, with the preference for higher control. Although the preference for the $\mathrm{CD}$ product was also for high levels of control, the differential was only 8.5. It would appear that for higher cost, higher risk products, control would be more important than for lower cost, lower risk products. One perception of control may be the consumer's feeling that they could return the product, if necessary, which would be much easier with a $\mathrm{CD}$ than with a computer. In accordance with the previous results, effort and subjective norms had the lowest level of importance for each of the product classes.

Pooled regression analysis was used to test for the differences between the product classes. ${ }^{1}$ Our results indicate that at $\alpha=0.05$, the only attribute that exhibits a statistically significant difference in importance scores between the product classes is control $(\mathrm{CD}=10.4 \% ; \mathrm{PC}=13.98 \%)$.

\section{$\underline{\text { Simulations }}$}

We used choice simulations to further validate the results of our studies ${ }^{2}$. By using conjoint simulations, we were able to translate the utility values for each of the retail alternatives into "market shares" to identify the impact of attributes on the consumers' selection of purchase format. These simulations give the probability of choosing a particular bundle of attributes as the most preferred. In order to classify the most realistic scenarios for each of the retail formats, we consulted the literature used for the study and identified the following situations which were used as baseline scenarios for each product class:

We like to thank an anonymous $J B R$ reviewer for this suggestion. 
(1) Internet format, little effort, a lot of control, 5\% subjective norm, negative attitude, and low price;

(2) Catalog format, little effort, little control, $85 \%$ subjective norm, positive attitude, and medium price; and

(3) Retail format, a lot of effort, little control, $85 \%$ subjective norm, positive attitude, and high price.

In our simulations, we used the maximum utility model and the logistic model (Wiley \& Low, 1983). With respect to the maximum utility model, the market shares of a simulated alternative reflects the probability of choice of the fraction of first choices divided by the total number of observations. The logistic model estimates the probability of choice by taking the natural $\log$ of dividing the utility of a simulated alternative by the sum of all simulation total utilities (Wiley \& Low, 1983).

$$
[\Leftarrow \text { Insert Table } 3 \text { about here } \Rightarrow]
$$

As can be seen in Table 3, we ran three simulations against the baseline, changing several of the attributes for each. Using this procedure, it is clear that there are certain effects by changing the attribute levels for each of the retail formats. In simulation $A$, the level of control was changed in the Internet and retail formats. By decreasing the level of control for the Internet format and increasing it in the retail format, for both product classes we are able to see the impact that control has on the purchase scenario. In conclusion with our previous results, the more control that is given, the more likely a consumer will chose the alternative with the most control, as can be seen by the increase choice for the retail alternative, which was much more drastic for the PC product class (CD: MU: +14.69; Logistic: 10.50; PC: MU: 21.74; Logistic: 16.87). This market share gain for the retail format can be mainly attributed to market share loss of the Internet format. Therefore, this is in line with our previous 
assumptions that the higher risk, higher cost alternative control would be more important that for the lower cost, lower risk products. In simulation B, we changed the level of attitude $\mathrm{b}$ positive for the Internet format. This leads to an increase of market share for the Internet format in the computer product class (MU: +12.32; Logistic: +12.09). An even more substantial increase can be observed in the CD product class (MU: +24.47; Logistic: +24.38). This gain in market share of the Internet format can be mainly attributed to a market share loss for the catalog format. These results are also in line with previous results where the importance for attitude was greater in the CD product class. The greater differential could be the cause that in a lower price, lower risk product, attitude might have more weight on the decision making process whereas in the higher price, higher risk product category it would still be important, but price might have more weight. In simulation $\mathrm{C}$, we changed the level of control to little control and the subjective norm to $85 \%$ for the Internet format and the level of control to a lot of control for the retail format. As can be observed, this results in considerable market share gains, although for different retail formats based on the product class. In the CD example, this simulation resulted in a considerable market share gain in the Internet format (MU: +11.89; Logistic: +12.10), whereas for the PC product class, most of the gains were for the retail format alternative (MU: +15.94 ; Logistic: +15.82 ). Again, we can see the impact that the level of control has on the higher risk, higher price product class of the PC. The more control the consumer has over the situation, the more likely they are to use that retail format. While for the lower risk, lower price CD product class, control did not enable consumers to choose the retail format over the Internet. In all simulations, catalogs lost market share potential, which would be in line with the current suggestions that catalogs will loose market share with the emergence of the Internet. 


\section{$\underline{\text { Cluster Analysis }}$}

Cluster analysis is identified by several past research studies as appropriate to use to segment conjoint analysis's utility values (Green \& Krieger, 1991; Johnson, 1995; Louviere, 1988; Moore \& Semenik, 1988). Clusters can be used to group the subjects according to some measure of distance, relatedness, or similarity between importance ratings or utility measures (Aldenderfer \& Blashfield, 1984). Once the clusters are identified, tests can be performed on various segmentation measures to identify what are the defining variables in the clusters (Green \& Krieger, 1991). Punj and Steart (1983) suggest a two-stage clustering approach. In the first stage, hierarchical clustering is used to determine the number of clusters and in the second stage, nonhierarchical is used to "fine-tune" the results.

\section{Hierarchical Clustering}

For hierarchical clustering, we used Ward's minimum variance method with Euclidian distance to obtain a preliminary solution. This method is designed to minimize the variance within the clusters as opposed to the variance between the clusters (Ward, 1963). We used the unstandardized importance weights as inputs in the hierarchical clustering procedure and to determine the number of clusters, we graphed the number of clusters against the fusion coefficient; an approach analogous to the "scree test" in exploratory factor analysis. Results for the both the $\mathrm{CD}$ product class and the PC product class showed that there were either four or five clusters present in the data. Subsequently, the centroids of the four-cluster solution and five-cluster solution were used as starting point for nonhierarchical clustering.

\section{Nonhierarchical clustering}

In the second stage, the K-means procedure with Euclidian distances was employed to "finetune" the results, as iterative or nonhierarchical clustering methods are superior to hierarchical clustering methods. For each product class, it was seen as appropriate to choose the proper numbers of clusters based on the number of respondents per cluster (Moore \& 
Semenik, 1988). After examining the results, it was found that four clusters were the most appropriate for the data. The five-cluster solution revealed that there were a few clusters that had twelve or less subjects in the cluster and since the distributions had small cells, four clusters were selected to segregate the data.

\section{Cluster Analysis Results for the CD Product Class}

After four clusters were chosen, additional analysis was run to determine the defining characteristics of the segments in the individual clusters. Since attribute importance was critical to the study, this variable was used to profile the clusters. In determining what was important to each cluster, several strong segments were identified. The results of the profile analysis for the CD sample are shown in Table 4.

$$
[\Leftarrow \text { Insert Table } 4 \text { about here } \Rightarrow]
$$

By examining the importance levels of each of the cluster, four very strong clusters are identified based on the level of importance for a particular attribute. This segments the data nicely by attribute importance. For the first cluster, subjects don't really have a particular attribute that is most important to them, rather it is the bundle of attributes that are important to this cluster. Therefore, there is not a particular attribute that is most important to this cluster, but instead it is the entire profile of the product experience that attracts them to make the purchase and so they were named the "Generalist" cluster.

In the second cluster, format is very prominently the defining reason why these subjects would make a purchase so they were named the "Formatters". This attribute has the most important value to the consumers. Most of these people in the sample will only purchase products in a retail store and would not even consider purchasing the $\mathrm{CD}$ in another format.

For the third cluster, the "Price Sensitives," price is the dominant driver as to why a subject would purchase the CD. These consumers are driven by price first, and then format 
second. Therefore, they will seek the lowest price, even if they have to purchase through the Internet or a catalog.

Attitude was the most important attribute for subjects in the fourth cluster. Previous positive experience with the retail format is the reason these subjects would make a purchase so this cluster was labeled the "Experiencers". Format was second in importance to this cluster, but attitude was twice as important to them when purchasing a CD.

In order to assure that each attribute importance score was significantly different for each cluster, one-way ANOVA was conducted on the importance scores for each of the attributes as the dependent variable and the cluster membership as the independent variable (See Table 4). These results suggest that each of the clusters can then be identified as different on which attribute the subjects' have placed the most importance on.

\section{Cluster Analysis for the Computer Product Class}

Since four clusters were appropriate for both the $\mathrm{CD}$ and the computer product classes, it was important to identify characteristics of these clusters. Since attribute importance was critical to the study and found to be significant in the CD product class, the profile analysis was also conducted for the computer product class. Just as in the CD product, several strong segments were identified. The results of the importance analysis for the computer sample are shown in Table 5.

$$
[\Leftarrow \text { Insert Table } 5 \text { about here } \Rightarrow]
$$

By examining the importance levels of each of the cluster, four very strong clusters are identified based on the level of importance for a particular attribute. These clusters correspond nicely to the clusters that were identified for the $\mathrm{CD}$ product class. For each product class, there was a segment that valued price as the most important attribute, the "Price Sensitives"; both product classes had a cluster that identified subjects who felt that format was more important to them (the "Formatters"); and each had a cluster that identified 
attitude as most important, the "Experiencers". The only difference was that for the CD sample, the "Generalists" cluster represented subjects that had very similar importance levels for each of the attributes (between $11 \%$ and 19\%), and athough the cluster for the computer product was similar, control was viewed as the most important attribute (25\%), with the other five attributes had very similar ratings (12\%-18\%), but each was labeled as "Generalists".

This suggests that for each product class, the segmentation is similarly based on importance ratings of attributes. It also strengthens the results that four attributes - mode, price, attitude, and control - had high importance ratings in the preliminary conjoint analysis and that is exactly how the subjects were clustered.

As with the $\mathrm{CD}$ product, it is important to validate that each attribute importance score was significantly different for each cluster. A one-way ANOVA was carried out on the importance scores for each of the attributes as dependent variable and cluster membership as independent variable (See Table 5). With this result, each of the clusters can then be identified as different from one another on which attribute the subjects' have placed the most importance.

These results are helpful since the clusters are so clearly defined by their attribute importance. By having such specific segments defined, it will have implications on many of the research and practical issues that are being raised by the entrance of the Internet into the retail marketplace.

\section{CONCLUSIONS}

Most experts agree that current retailing trends show a shift from traditional store-based retailing to an increased use of the Internet. Store based retailers have great concern that the Internet will make the store obsolete. This fear has driven many of them to build an expensive Internet presence. The findings from the structure of the consumer decisionmaking process in this study clearly show that, under the hypothetical situations provided in 
the research, retail stores may have a large advantage over both catalogs and the Internet. The utility scores rank in the order that consumers are currently spending - the most money is spent in retail stores, and then catalogs and finally, the Internet. The importance scores indicate that retail format may still be the first choice for consumers and the utility scores underscore the advantage that retail stores currently have in the market place.

It should be pointed out that the structure of the consumer decision is not a static structure but is tied to a particular place and time. It would be expected that as the retail landscape and consumer experiences change, the structure uncovered in this study would also change. Thus, the conclusions about the strength or weakness of the Internet and the value of important decision factors is of this time and not of the future.

This study examined attributes that were identified in previous literature on acceptance of technology from two modifications of the theory of reasoned action: the technology acceptance model and the theory of planned behavior. From research on these two models, five variables were identified as applicable to examining technology use: 1) subjective norms, 2) attitude, 3) perceived behavioral control, 4) ease of use, and 5) price.

Consumers rated profiles on their intention to purchase under the hypothetical conditions outlined in the profiles. Each profile had one level of each of the six attributes. Importance ratings and utility scores were identified by the conjoint analysis for each individual and for the aggregate data. Aggregate data was the primary analysis for the research. The use of conjoint analysis allowed a unique look at both the structure of the decision as well as the relative impact of levels of the factors in the decision.

The structure of the retail decision process was found to be primarily one of choosing the format (store, catalog, or Internet) and price desired. Both of these factors were twice as important as the possible other factors of ease of use, control, subjective norm, and attitude (positive or negative). The strength of retail format suggests that the choice of where a 
consumer will shop may occur first and independent of a formula based on attributes and information. Thus, stores that have the greatest market share will, for the near term, have a large advantage in the market place. Fears that the Internet will take over the retail arena seem thus overblown and exaggerated. However, there seems to be an identifiable segment of customers that has a preference for the Internet as a retail shopping alternative.

\section{STUDY LIMITATIONS AND THEIR IMPLICATIONS}

The results of this research must be taken in light of some limitations. In this research, only two extensions of the theory of reasoned action are discussed and tested. Other theories that identify other possible important attributes clearly exist and should be tested.

The theory of reasoned action, the technology acceptance model, and the theory of planned behavior are not without their criticisms. For example, the models require that individuals are motivated to perform a given behavior, which is problematic when studying consumer adoption behaviors. Also, the models assume identical belief structures across respondents. While these theories are robust in predicting a wide variety of behaviors, these limitations provide boundaries to the generalizations of its results.

Caution must be exhibited when translating expectations to purchase via the Internet to actual behavior in the market. The novelty of this shopping alternative may also limit its generalizability. Examining a new innovation at an early stage in the diffusion process may not be typical of results that would be revealed in a later stage of adoption. The advantages of the Internet feed into those factors that consumers say are important in making a decision high degrees of control, ease of effort, lower price, and positive experience.

This research also prescribes what Internet retailers need to do to attract consumers. They should emphasize their high degrees of control (7 days a week, no out of stock, 24 hours a day, no parking hassles, 365 days a year, and many other things) and their ease of use (simple clicks get you what you want). They should emphasize lower prices that are possible because 
Internet companies do not have the expense of brick and mortar (less personnel, no taxes paid by the consumer). Most importantly, Internet retailers must insure that consumers have a positive experience each and every time the consumer visits.

Another point, which is valid for both the traditional retail alternatives and e-retailers, is that they must realize that the competitive structure of the retail environment has dramatically changed. Customers now consider both catalogs and the Internet as a viable alternative to the more traditional retail store. As Balasubramanian (1998) shows from a retailer perspective, remotely situated alternatives (catalogs and the Internet) are a threat to competition, just as much as other "neighborhood" stores are. Therefore, areas of the country that have a high market penetration of Internet shoppers should be a "red flag" for retailers who are thinking of moving into the area, as competition would be greatly affected by this situation.

The distribution of information should also be examined by both traditional and eretailers. Since Internet and catalog retailers may have an advantage over the extent of customer information they have access to, which traditional store retailers do not, the level of control from an information standpoint needs to be examined by the store retailers. While store retailers typically send marketing information to customers that is quite general in nature, Internet and catalog retailers can provide customers with more targeted one-to-one direct marketing campaigns. In line with Balasubramanian's (1998) findings, retailers can only effectively compete with other retailers in areas that have very small amount of catalog and Internet penetration. This makes the job of the Internet and catalog retailers also more difficult, since there are very few areas of the market that have no retail store penetration. They must also take into account costs and consumer prices to see which is the best tool for competing with the traditional store retailers (product offering, service, price or information). Therefore, with these things in mind, and since retailers cannot realistically send information 
to every customer in the marketplace, the question for all retail alternatives becomes which customers do they send their information to in order to make it most effective?

\section{DIRECTIONS FOR FUTURE RESEARCH}

The growth of electronic shopping will have major implications for the marketing of consumer goods. For example, existing channel and power relationships could change dramatically, if manufacturers, agencies, and media owners start to by-pass existing retailers. The possible reduction of market share may have significant implications for investors in, and operators of, major stores and malls. More research is needed to assess these phenomena. Other situations, besides CDs and computer purchases, could also be examined to see if differences arise in the type of retail product or service would affect a consumer's intention to purchase via the Internet.

In this study, no situational influences were manipulated. Influences, such as time pressures, may be examined in future research, or the presence of other customers (crowding). Like this research, crowding would be better tested on a larger population than students since undergraduates (and some graduate students) are more used to the situation when dealing with technology usage (long lines in computer labs, several hundred computers in one room).

Another influence that was not explored in this research was the differences between expert and novice Internet users. There may be differences in their intention behavior based on their skill, which should be addressed in future studies. Finally, we acknowledge that it may have been preferable to use a choice-based, rather than a full-profile conjoint methodology to obtain a valid assessment of consumer preferences. In future research, both methodologies should be compared in order to validate our findings. 


\section{APPENDIX A: SAMPLE PROFILES}

\section{PROFILE A}

You decide to use the Internet to purchase the CD.

Purchasing the CD on-line takes a lot of effort.

Buying the CD on-line gives you little control over the purchase.

$\mathbf{8 5 \%}$ of the people important to you have made an on-line purchase like this.

You had an unpleasant buying experience the last time you purchased a CD on-line.

The CD costs \$13.99.

Likelihood of purchase (0-100):

\section{PROFILE B}

You decide to buy the computer from a mail-order catalog.

Purchasing through a catalog takes little effort.

Buying the computer through a catalog gives you little control over the purchase.

$\mathbf{8 5 \%}$ of the people important to you have made a catalog purchase like this.

You had an unpleasant buying experience the last time you purchased a computer by catalog. The computer costs $\$ \mathbf{1 , 1 9 9 . 9 9}$.

Likelihood of purchase (0-100): 


\section{REFERENCES}

Adams, D. A., Nelson, R. R., and Todd, P. A., Perceived Usefulness, Ease of Use, and Usage of Information Technology: A Replication. MIS Quarterly 16 (Summer 1992): 227-247.

Addelman, S., Orthogonal Main-Effect Plans for Asymmetrical Factorial Experiments. Technometrics 4 (February 1962): 21-58.

Ajzen, I., and Fishbein, M., Understanding Attitudes and Predicting Behavior, Prentice Hall, Englewood Cliffs, NJ. 1980.

Ajzen, I., Attitudes, personality and behaviors, Dorsey Press, Chicago, IL. 1988.

Ajzen, I., The Theory of Planned Behavior. Organizational Behavior and Human Decision Processes 50 (1991): 179-211.

Aldenderfer, M. S., and Blashfield, R. K., Cluster Analysis, Sage Publications, Newbury Park, CA. 1984.

Bagozzi, R. P., and Kimmel, S. K., A Comparison of Leading Theories for the Prediction of Goal-Directed Behaviors. British Journal of Social Psychology 34 (1995): 437-461.

Balasubramanian, S., Mail versus Mall: A Strategic Analysis of Competition between Direct Marketers and Conventional Retailers. Marketing Science 17 (1998): 181-195.

Bateson, J. E. G., Self-Service Consumer: An Exploratory Study. Journal of Retailing 61 (March 1985): 49-76.

Blair, E., Sampling Issues in Trade Area Maps Drawn From Shopper Surveys. Journal of Marketing 47 (Winter, 1983): 98-106.

Boston Consulting Group, The State of Online Retailing. (November 1998).

Bush, A. J., and Hair, Jr., J. F., An Assessment of the Mall Intercept as a Data Collection Method. Journal of Marketing Research 22 (1985): 158-167.

Carroll, J. D., and Green, P. E., Psychometric Methods in Marketing Research: Part I, Conjoint Analysis. Journal of Marketing Research 32 (November 1995): 385-391. 
Dabholkar, P. A., Consumer Evaluations of New Technology-Based Self-Service Options: An Investigation of Alternative Models of Service Quality. International Journal of Research in Marketing 13 (1996): 29-51.

Dabholkar, P. A., Role of Affect and Need for Interaction in On-Site Service Encounters. Advances in Consumer Research 19 (1992): 563-569.

Davis, F. D., A Technology Acceptance Model for Empirically Testing New End-User Information Systems: Theory and Results, Unpublished doctoral dissertation, Massachusetts Institute of Technology, Boston, MA. 1986.

Davis, F. D., and Venkatesh, V., A Critical Assessment of Potential Measurement Biases in the Technology Acceptance Model: Three experiments. International Journal of Human Computer Studies 45 (1996): 19-45.

Davis, F. D., Bagozzi, R. P., and Warshaw, P. R., User Acceptance of Computer Technology: A Comparison of Two Theoretical Models. Management Science 35 (August 1989): 9821003.

Davis, F. D., Perceived Usefulness, Perceived Ease of Use, and User Acceptance of Information Technology. MIS Quarterly 13 (1989): 319-340.

Davis, F. D., User Acceptance of Information Technology: System Characteristics, User Perceptions and Behavioral Impacts. International Journal of Man-Machine Studies 38 (1993): 475-487.

Ernst \& Young, Internet Shopping: A Special Report. Report presented at the National Retail Federation Conference, New York. January 1998.

Ernst \& Young, The Second Annual Internet Shopping Study. Report presented at the National Retail Federation Conference, New York. January 1999.

Fishbein, M., and Ajzen, I., Belief, Attitude, Intention and Behavior, Addison-Wesley, Reading, MA. 1975. 
Forrester Research, Inc., On-Line Retail Strategies Report. 1999. [On-line]. Available: www.forrester.com/research.

Forrester Research, Inc., Retail's Growth Spiral. 1998. [On-line]. Available: www.nrf.com/ ecommerce/forrester/1998/reports/2642/document.htm.

Green, P. E., and Srinivasan, V., Conjoint Analysis in Consumer Research: Issues and Outlook. Journal of Consumer Research 5 (1978): 103-123.

Green, P. E., and Srinivasan, V., Conjoint Analysis in Marketing: New Developments With Implications for Research and Practice. Journal of Marketing 4 (1990): 3-19.

Green, P. E, and Krieger A. M., Segmenting Markets with Conjoint Analysis. Journal of Marketing 55 (October 1991): 20-31.

Hill, T., Smith, N. D., and Mann, M. F., Role of Efficacy Expectations in Predicting the Decision to Use Advanced Technologies: The Case of Computers. Journal of Applied Psychology 72 (February 1987): 307-313.

Johnson, R. B., Estimating an Evaluation Utilization Model Using Conjoint Measurement and Analysis. Evaluation Review 19 (March 1995): 313-339.

Louviere, J. J., Analyzing Decision Making: Metric Conjoint Analysis, Sage Publications, Newbury Park, CA. 1988.

Madden, T. J., Ellen, P. S., and Ajzen, I., A Comparison of the Theory of Planned Behavior and the Theory of Reasoned Action. Personality and Social Psychology Bulletin 18 (1992): 3-9.

Mathieson, K., Predicting User Intentions: Comparing the Technology Acceptance Model with the Theory of Planned Behavior. Information Systems Research 2 (1991): 173-191.

Moore, G. C., and Benbasat, I., Development of an Instrument to Measure the Perceptions of Adopting an Information Technology Innovation. Innovation Systems Research 2 (March 1991): 192-222. 
Moore, W. L., and Semenik, R. J., Measuring Performances with Hybrid Conjoint Analysis: The Impact of a Different Number of Attributes in the Master Design. Journal of Business Research 16 (1988): 261-274.

Nataraajan, R., Prediction of Choice in a Technically Complex, Essentially Intangible, Highly Experiential, and Rapidly Evolving Consumer Product. Psychology and Marketing 10 (May 1993): 367-379.

Nielsen Media Research and CommerceNet, Shoppers Filling On-Line Carts With Books, Computer Stuff. (October 8, 1999, press release). [On-line]. Available: www.nielsenmedia.com/news.

Punj, G., and Stewart, D. W., Cluster Analysis in Marketing Research: Review and Suggestions for Application. Journal of Marketing Research, 20 (May 1983): 134-148.

Sheppard, B. H., Hartwick, J., and Warshaw, P. R., The Theory of Reasoned Action: A MetaAnalysis of Past Research with Recommendations for Modifications and Future Research. Journal of Consumer Research 15 (December 1988): 325-343.

Sudman, S., Improving the Quality of Shopping Center Sampling. Journal of Marketing Research 17 (November 1980): 423-431.

Surprenant, C. F., and Solomon, M. R., Predictability and Personalization in the Service Encounter. Journal of Marketing 51 (February 1987): 86-96.

Taylor, S., and Todd, P., Decomposition and Crossover Effects in the Theory of Planned Behavior: A Study of Consumer Adoption Intentions. International Journal of Research in Marketing 12 (February 1995): 137-155.

Ward, J., Hierarchical Grouping to Optimize an Objective Function. Journal of the American Statistical Association 58, (1963): 236-244.

Wiley, J. B. and Low, J. T., A Monte Carlo Simulation Study of Two Approaches for Aggregating Conjoint Data. Journal of Marketing Research 20, (1983): 405-416. 
Figure 1: Importance Scores for Each Product Class

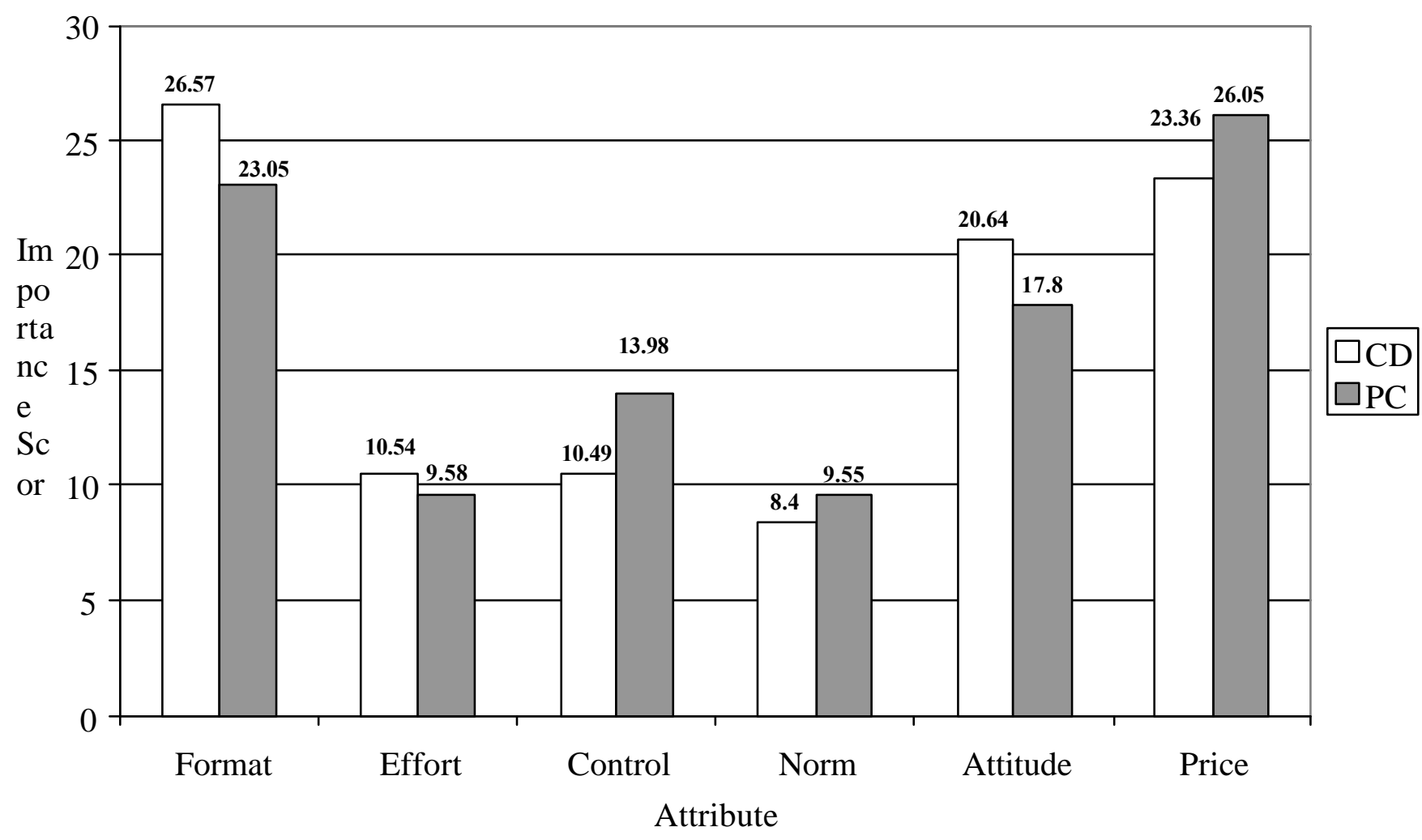


Table 1: Sample Characteristics for Each Product Class

\begin{tabular}{|c|c|c|c|c|c|}
\hline \multirow[t]{3}{*}{ Variable } & \multirow[t]{3}{*}{ Categories } & \multicolumn{4}{|c|}{ Product Class } \\
\hline & & \multicolumn{2}{|c|}{ CD } & \multicolumn{2}{|c|}{$\mathbf{P C}$} \\
\hline & & $\mathbf{n}$ & $\%$ & $\mathbf{n}$ & $\%$ \\
\hline \multirow[t]{2}{*}{ Gender } & Male & 71 & 49.7 & 65 & 47.8 \\
\hline & Female & 72 & 50.3 & 71 & 52.2 \\
\hline \multirow[t]{3}{*}{ Age } & 18-25 years & 58 & 40.6 & 49 & 35.5 \\
\hline & 26-35 years & 53 & 37.1 & 52 & 37.7 \\
\hline & $>35$ years & 32 & 22.4 & 37 & 26.8 \\
\hline \multirow[t]{3}{*}{ Income } & $<\$ 25,000$ & 79 & 56.5 & 77 & 57.0 \\
\hline & $\$ 25,000-55,000$ & 32 & 22.8 & 30 & 22.2 \\
\hline & $>\$ 55,000$ & 17 & 20.7 & 28 & 20.8 \\
\hline Level of & High school (and some college) & 26 & 18.4 & 26 & 19.7 \\
\hline \multirow[t]{2}{*}{ Education } & College grad. & 61 & 43.3 & 45 & 34.1 \\
\hline & Graduate school & 54 & 38.3 & 61 & 46.2 \\
\hline \multirow[t]{2}{*}{ Marital Status } & Married & 65 & 45.8 & 60 & 43.5 \\
\hline & Single or divorced & 77 & 54.2 & 78 & 56.6 \\
\hline
\end{tabular}


Table 2: Importance Scores and Part-Worth Utilities per Level for Each Product Class

\begin{tabular}{|c|c|c|c|c|c|}
\hline \multirow[b]{2}{*}{ Group } & & \multicolumn{2}{|c|}{ Importance Score (\%) } & \multicolumn{2}{|c|}{ Part-Worth Utility } \\
\hline & & CD & PC & CD & $\mathbf{P C}$ \\
\hline \multirow[t]{3}{*}{ Format } & Internet & 26.57 & 23.05 & -9.77 & -4.47 \\
\hline & Catalog & & & -4.79 & -3.08 \\
\hline & Retail & & & 14.55 & 7.54 \\
\hline \multirow[t]{2}{*}{ Effort } & A little & 10.54 & 9.58 & 4.89 & 3.55 \\
\hline & A lot & & & -4.89 & -3.55 \\
\hline \multirow[t]{2}{*}{ Control } & A little & 10.49 & 13.98 & -4.24 & -6.64 \\
\hline & A lot & & & 4.24 & 6.64 \\
\hline \multirow[t]{2}{*}{ Norm } & $5 \%$ & 8.40 & 9.55 & -2.39 & -2.61 \\
\hline & $85 \%$ & & & 2.39 & 2.61 \\
\hline \multirow[t]{2}{*}{ Attitude } & Positive & 20.64 & 17.80 & 11.45 & 9.18 \\
\hline & Negative & & & -11.45 & -9.18 \\
\hline \multirow[t]{3}{*}{ Price } & Low & 23.36 & 26.05 & 7.72 & 9.56 \\
\hline & Medium & & & 3.96 & 2.30 \\
\hline & $\mathrm{High}$ & & & -11.69 & -12.56 \\
\hline
\end{tabular}


Table 3: Results of Simulations

\begin{tabular}{|c|c|c|c|c|c|c|c|c|c|}
\hline \multirow[t]{2}{*}{ Simulation } & & \multicolumn{4}{|c|}{ CD } & \multicolumn{4}{|c|}{ PC } \\
\hline & & $\begin{array}{l}\text { MU Model } \\
(\%)^{\mathrm{a}}\end{array}$ & $\begin{array}{l}\text { Change } \\
\text { (in \%) }\end{array}$ & $\begin{array}{l}\text { Logistic } \\
\text { Model (\%) }\end{array}$ & $\begin{array}{l}\text { Change } \\
\text { (in \%) }\end{array}$ & $\begin{array}{l}\text { MU Model } \\
\text { (\%) }\end{array}$ & $\begin{array}{l}\text { Change } \\
\text { (in \%) }\end{array}$ & $\begin{array}{l}\text { Logistic } \\
\text { Model (\%) }\end{array}$ & $\begin{array}{l}\text { Change } \\
\text { (in \%) }\end{array}$ \\
\hline \multirow[t]{3}{*}{ Baseline } & Internet & 22.38 & $\mathrm{na}^{\mathrm{b}}$ & 22.75 & na & 43.48 & na & 41.59 & na \\
\hline & Catalog & 41.96 & na & 43.69 & na & 33.70 & na & 36.33 & na \\
\hline & Retail & 35.66 & na & 33.56 & na & 22.83 & na & 22.08 & na \\
\hline \multirow[t]{3}{*}{ Simulation A } & Internet & 11.89 & -10.49 & 13.37 & -9.38 & 20.29 & -23.19 & 21.69 & -19.90 \\
\hline & Catalog & 37.76 & -4.20 & 42.58 & -1.11 & 35.14 & +1.44 & 39.36 & +3.03 \\
\hline & Retail & 50.35 & +14.69 & 44.06 & +10.50 & 44.57 & +21.74 & 38.95 & +16.87 \\
\hline \multirow[t]{3}{*}{ Simulation B } & Internet & 46.85 & +24.47 & 47.13 & +24.38 & 55.80 & +12.32 & 53.68 & +12.09 \\
\hline & Catalog & 23.78 & -18.18 & 24.90 & -18.79 & 21.38 & -12.32 & 24.71 & -11.62 \\
\hline & Retail & 29.37 & -6.29 & 27.97 & -5.59 & 22.83 & 0.00 & 21.61 & -0.47 \\
\hline \multirow[t]{3}{*}{ Simulation C } & Internet & 34.27 & +11.89 & 34.85 & +12.10 & 45.65 & +2.17 & 45.03 & +3.44 \\
\hline & Catalog & 23.78 & -18.18 & 25.34 & -18.35 & 15.58 & -18.12 & 17.07 & -19.26 \\
\hline & Retail & 41.96 & +6.30 & 39.81 & +6.25 & 38.77 & +15.94 & 37.90 & +15.82 \\
\hline
\end{tabular}

a Maximum utility model.

b Not applicable. 
Table 4: Profile Analysis for Clusters in CD Product Class

\begin{tabular}{|c|c|c|c|c|c|c|}
\hline \multirow[t]{3}{*}{ Attribute } & \multicolumn{3}{|c|}{ Importance Score (\%) } & \multicolumn{3}{|c|}{ Oneway-Anova } \\
\hline & Generalists & Formatters & Price Sensitives & Experiencers & $\mathbf{F}$ & p-value \\
\hline & $(n=50)$ & $(n=21)$ & $(n=41)$ & $(n=31)$ & & \\
\hline Format & 19.27 & 66.09 & 20.44 & 16.69 & 91.32 & $\mathrm{p}<0.001$ \\
\hline Effort & 16.25 & 3.45 & 7.79 & 9.78 & 20.34 & $\mathrm{p}<0.001$ \\
\hline Control & 16.61 & 4.87 & 7.82 & 7.94 & 18.99 & $\mathrm{p}<0.001$ \\
\hline Norm & 10.47 & 4.17 & 7.98 & 8.50 & 4.85 & $\mathrm{p}=0.003$ \\
\hline Attitude & 18.68 & 7.84 & 14.61 & 40.43 & 86.83 & $\mathrm{p}<0.001$ \\
\hline Price & 18.71 & 13.58 & 41.36 & 13.66 & 85.27 & $\mathrm{p}<0.001$ \\
\hline
\end{tabular}


Table 5: Profile Analysis Clusters in PC Product Class

\begin{tabular}{|c|c|c|c|c|c|c|}
\hline \multirow[t]{3}{*}{ Attribute } & \multicolumn{3}{|c|}{ Importance Score (\%) } & \multicolumn{3}{|c|}{ Oneway-Anova } \\
\hline & Experiencers & Formatters & Generalists & Price Sensitives & $\mathbf{F}$ & p-value \\
\hline & $(n=37)$ & $(n=23)$ & $(n=45)$ & $(n=33)$ & & \\
\hline Format & 16.94 & 54.34 & 18.09 & 14.86 & 84.31 & $\mathrm{p}<0.001$ \\
\hline Effort & 10.69 & 6.34 & 12.27 & 6.91 & 6.99 & $\mathrm{p}<0.001$ \\
\hline Control & 7.78 & 6.22 & 25.30 & 10.88 & 40.34 & $\mathrm{p}<0.001$ \\
\hline Norm & 8.52 & 7.85 & 12.40 & 8.00 & 3.81 & $\mathrm{p}=0.012$ \\
\hline Attitude & 34.78 & 8.58 & 13.84 & 10.57 & 91.38 & $\mathrm{p}<0.001$ \\
\hline Price & 21.29 & 16.67 & 18.09 & 48.79 & 83.19 & $\mathrm{p}<0.001$ \\
\hline
\end{tabular}

